\title{
IUELTAL
}

\section{Designing English Listening Materials through YouTube Video Editing: Training for English Teachers of Islamic Junior High Schools, Parepare, South Sulawesi}

\author{
Zulfah Fakhruddin \\ IAIN Parepare, Indonesia \\ e-mail:fakhruddin.zulfah@yahoo.com
}

\author{
Usman \\ IAIN Parepare, Indonesia \\ e-mail:usmannoer@gmail.com
}

\section{Rahmawati}

IAIN Parepare, Indonesia

e-mail:rahmawati@iainpare.ac.id

\section{Sulvinajayanti}

IAIN Parepare, Indonesia

e-mail:sulvinajayanti@iainpare.ac.id

\begin{abstract}
:
This study was conducted to help English teachers in designing English listening materials in form of audio and textbook through YouTube video editing. 18 English teachers of 10 Islamic junior high schools in Parepare were trained to write English listening materials in form of textbook and to edit video (download, import, cut, merge, and export video) in form of audio.150 students were observed and tested to evaluate teachers' products. Training materials consist of: (1) searching and download video through YouTube, (2) editing video that includes import, cut, merge, and export video, and (3) writing worksheet that contains phoneme discrimination dan listening comprehension exercise in form of multiple choice, true false, and completion. Training activities include: (1) explanation, (2) practice, (3) grouping, (4) assignment/design, and (5) evaluation and revision. After following training, teachers' ability was categorized into good and fair in designing English listening materials. More than 50\%
\end{abstract}


teachers were categorized into good in editing video and $72 \%$ teachers were categorized into good in writing listening exercise. Students' English listening learning outcome was categorized into good after learning by using teachers' products and students have positive attitude in learning English listening skill.

Keywords: audio, editing, listening material, textbook

\section{Introduction}

The issue of developing teaching materials, especially the development of information technology-based English teaching materials has become a trending topic in the current field of education and teaching in English in Indonesia. Information technology in the form of the internet provides information search sites such as Google, YouTube, online news, and other online sites that can be used as authentic sources or references of teaching material. Multimedia tools such as audio, video, computers, software, and internet material are considered effective and authentic tools that can help students succeed in learning in reallife contexts (Sejdiu, 2017). Authentic teaching materials for developing teaching materials are not only able to improve students' English knowledge and skills but also to increase students' interest in learning English (Johansson, 2006).

The development of teaching materials, especially English listening materials is adjusted to the level of student needs, the level of students' abilities, and learning characteristics in the Islamic Junior High School environment. This statement is in line with the research results of Yavuz, Değirmenci, Akyüz, Yılmaz, \& Çelik (2015), that it is important to apply tasks that are appropriate to the level of students' needs and abilities in listening learning. Moreover, Gilakjani \& Sabouri (2016) stated that in listening skill learning, teaching materials must be tailored to the needs of students and teachers must provide authentic material for students so that they understand better natural sayings spoken by native speakers. In addition, the teacher must design listening task that arouse student interest and help them learn English listening skills. The task is not only to test students' listening comprehension but also to motivate them to use various types of listening strategies in order to get maximum benefits in carrying out their activities.

Teacher is the main reference or sources in the teaching and learning process while most teachers use textbooks and student worksheets as their main teaching resources. In this case, a teacher must be able to choose references or teaching materials that are appropriate to the level of students' needs and ability. Tomlinson (2012) stated that for more than 30 years, studies of the effectiveness of textbooks as a medium for delivering language learning materials have been widely discussed among researchers and instructors. The use of text books is efficient in cost and time. However, many commercial textbooks are not relevant to the actual needs and desires of students.

The problem mostly found in textbooks is the lack of listening skill material. Many textbooks ignore listening material (Gilakjani \& Sabouri, 2016). In addition, in some schools, teachers use some recording material that does not have high quality (Bingol, Celik, Yildiz, \& Mart, 2014). Some teachers and students consider listening is not important to be taught or learned. It causes students experience many difficulties in listening because teachers often ignore listening lessons and prioritize writing, reading, and vocabulary skills even 
though listening skill is one of the important skills in the communication process because listening skill is integrated with speaking skills (Osada, 2004).

The situation above is caused by the teacher's lack of ability to teach listening and inadequate audio-visual teaching facilities. According to Alrawashdeh \& Al-zayed (2017), the teachers consider teaching listening training is not important and they are not motivated to teach listening because the method of teaching listening is considered too difficult. The teacher's difficulties in teaching listening skills related to the use of technology. Mafuraga \& Moremi (2017) stated that the lack of ICT knowledge is caused by limited ICT training on how to instill ICT into teaching English.

Based on data preliminary study gathered from interview to eighteen English teachers of Islamic junior high schools in Parepare for one month, it was found that teachers' problem in teaching English listening skills and potency to solve the problem. The problem was teachers ignore to teach English listening skills because of some reasons. First, listening cassette or CD is hard to find; second, English textbooks don't prepare teaching materials for listening skill/textbooks are not equipped with listening audio material or CD; third, price of listening materials is expensive; fourth, the materials difficulty level isn't suitable for junior high school students; and fifth, teachers aren't able to prepare English listening material by themselves. These cause students almost never learn English listening skills. Then, to solve the teachers' problem, researchers used some potencies teachers have. They are: (1) teachers have computer, laptop, and smartphone, (2) internet network is very good, and (3) internet credit is cheap. Therefore, researchers provided YouTube video editing training to help teachers to provide English listening materials.

In this study, researchers administered research questions as follow:

1. How does YouTube video editing training help teachers in designing English listening materials?

2. What is teachers' ability in designing English listening materials after following training?

3. What is the effect of teachers' materials design toward English listening learning?

\section{Literature Review}

English curriculum in Indonesia stated that the goal of English listening skill teaching for Junior high schools students is students understand meaning of simple interpersonal and transactional oral discourse, formally and informally, in the form of recount, narrative, procedure, descriptive, and report, in the context of everyday life. Therefore, English listening material is generally prepared in form of dialogue and monologue in some listening situations such as listening conversation, announcement, news, entertainment, songs, lessons, lectures, and instructions (Kadagidze, 2006).

Listening material is one of problems in teaching listening (Renukadevi, 2014). The problem relates to the quality of listening materials and the conformity between listening materials and curriculum. The quality of listening materials includes speed and sound clarity. Renandya \& Farrell (2011) reported that the most important source of their listening comprehension problem was the fast rate of speech. Hayati (2010) examined the effect of slow and natural speech rate on listening comprehension and the finding showed that the 
two speech rate can improve students' listening comprehension significantly however, natural speech rate can give higher improvement than slow rate. Then, Hamouda (2013) stated that unclear sound was caused by poor quality equipment. It can influence students' comprehension because students get difficulties in identifying sound.

The conformity between listening materials and curriculum should be considered by teachers in preparing English listening materials. Curriculum was organized based on students' need. Curriculum consists of learning goals and content, skill, and value that have to be taught (Howard \& Major, 2004). The conformity will help teachers to achieve learning goals. Ross (2007) stated that effective teaching occurred when teaching materials were in line with learning goals.

YouTube is an online video sharing media website. YouTube users can upload videos, search videos, watch videos, discuss / ask questions about videos and at the same time share video clips so YouTube is very potential to be used as a learning medium and learning resource, especially for English listening learning. The purpose of utilizing YouTube as a learning medium is to create conditions and an interesting learning atmosphere, fun and interactive. Some researchers reported the effectiveness of YouTube in EFL teaching. Almurashi (2016), stated that you-tube can be used as teaching material to improve students' understanding and make students more active in the process of learning English. Woottipong (2014) found that students have positive learning attitudes and their listening skills also increase significantly by using videos in listening learning. Chen (2016) also found in his research that students prefer audio-visual material to learn listening skills and they can find the material through YouTube.

\section{Research Methodology}

This study used mix method to describe materials, process, and effectiveness of YouTube video editing training. Qualitative method was used to describe training materials, training activity, products' use, products' quality, products' revision, teachers' ability, and students' learning attitude. Quantitative data was used to describe students' learning outcome and to support qualitative data of teachers' ability in designing products.

This study was conducted in 10 Islamic Junior High Schools in Parepare, South Sulawesi, Indonesia which consist of 1 State Islamic Junior High School, 7 Private Islamic Junior High Schools, and 2 Islamic Boarding Schools. The subject of the research was 18 English teachers that consist of 14 female and 4 male; and 150 students of the first grade.

Data was collected by using observation, interview, and exercise. Observation and interview were used to collect data about teachers' ability in designing the products and teachers' perception toward the use of products and students' attitude in learning listening by using teachers' product. Then, exercise in teachers' product was used to collect data about students' learning outcomes.

Data about teachers' ability and perception in designing their English listening materials; and students' attitude in learning listening by using teachers' product were analyzed qualitatively. The data was organized, transcribed, categorized, and concluded (Creswell, 2008). Data about students' learning outcome was analyzed quantitatively by using scoring and frequency and percentage formulation. Scale of students' score is $0-100$. Students' 
score was categorized into 4 categories: 86 - 100 is very good $(A), 70-85$ is good (B), $56-69$ is fair (C), $\leq 55$ is poor (D). (Kebudayaan, 2015)

\section{Findings}

\subsection{YouTube video editing training}

The training was administered in two activities, training and mentoring. Training aimed to design English listening materials in form of audio and worksheet while mentoring aimed to revise teachers' material design. Plomp(2013) stated process of educational and instructional design consists of analysis, design, evaluation, and revision. Therefore, the process of the training was conducted as follow:

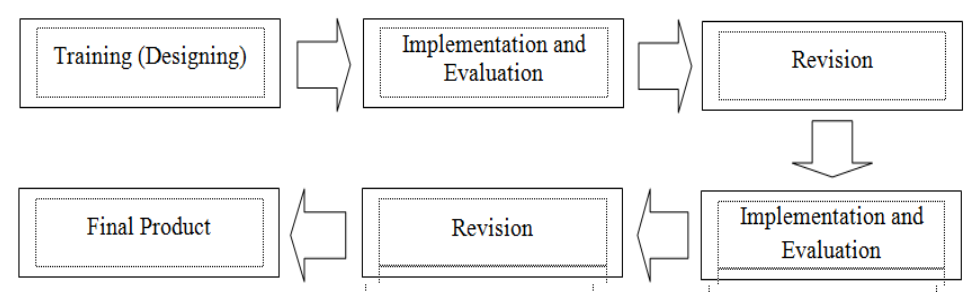

\subsubsection{Training}

Training materials consist of: (1) searching video and download video through YouTube, (2) editing video that includes import, cut, merge, and export video, and (3) writing textbook that contains phoneme discrimination dan listening comprehension exercise in form of multiple choice, true false, and completion.

1. Search and download: to search video in YouTube that can be used as learning materials. The video contents were about greeting, self-introduction, asking information, and giving direction or instruction in form of monologue, dialogue or conversation and song. Then, videos were downloaded before they were processed for the next step.

2. Import: to put download videos to editing media. The videos contain learning materials and music.

3. Cut: to take necessary part of video and deleting unnecessary part. It is also used to give pause between one number to other numbers and between one activity to other activity.

4. Merge: to combine video clips to become a new video.

5. Export: to change video into audio materials.

6. Phoneme discrimination exercise: to identify or to distinguish sound, stress, and intonation.

7. Listening comprehension exercise: to comprehend conversation, instruction, direction, description, and explanation.

The following is training activity:

1. Explanation: teachers got explanation about listening skill exercise models and the way to search, download, and edit video.

2. Practice: teachers practiced the way to search, download, edit video, and design listening exercise in form of textbook.

3. Grouping: teachers were divided into 5 groups. Each group consisted of 3 or 4 teachers. Teachers worked together in a group to make 1 chapter. 
4. Assignment (design): Every group made 1 chapter of English listening materials with different topic. The topics were taken from curriculum. They were greeting, selfintroduction, asking information about time and place, asking information about things in the classroom, and giving direction or instruction. Teachers designed listening materials in form of audio and textbook. 1 chapter consisted of 3 or more activities that contained phoneme discrimination and listening comprehension in form of completion, true-false, and multiple-choices.

5. Evaluation and revision: teachers' works were evaluated to find out the weakness of teachers' works and teachers' difficulties in designing audio and textbook. Then, revision was conducted to improve teachers' works.

After following training in designing English listening materials (product), the teachers still found some difficulties as follows:

1. Finding videos that match with learning objective.

2. Adjusting between video and exercise model.

3. Writing valid exercise model in construct.

4. Cutting and merging videos.

The following is examples of invalid materials in construct made by teachers:

\section{The first example}

In audio, students hear:

$\begin{array}{ll}\text { Man } & \text { : Hallo! } \\ \text { Woman } & \text { : Hallo Bill! } \\ \text { Man } & \text { : How are you doing? } \\ \text { Woman } & \text { : Not bad. Work is going well. } \\ \text { Man } & \text { : Oh, I see. That is good to hear. } \\ \text { Woman } & \text { : What's about you. } \\ \text { Man } & \text { : I am doing okay although my car is in shop. } \\ \text { Woman } & : \text { Oh really, that is too bad. }\end{array}$

In textbook, it is written:

Direction: Listen carefully, then circle $T$ if you think a statement true or circle $F$ if you think a statement false!
1. The woman is well
$[T / F]$
2. The woman's work is not going well.
$[T / F]$
3. I'm doing okay although my car is in shop
$[T / F]$

Question number 3 is not constructively valid because it is not in accordance with the purpose of the test. This test is a listening comprehension exercise model, while question number 3 is more likely to lead to the discrimination exercise model. Then, word "I" is very confusing for students. "I" can refer to man or woman. The sentence in question number 3 should be reformulated into the man is doing okay although his car is in shop. "I" should be replaced by "man" or "woman". 


\section{The second example}

In audio, students hear:

Number one : They go to school in the morning

Number two : Is your birthday on Friday?

Number three : We work in the afternoon and at night.

In textbook, it is written:

Direction: Listen the audio carefully and arrange the following words into a good sentence!

1. in - they-go-the-morning - school - to.

2. is - ?-birthday-Friday-on-your.

3. Work - and-at night-afternoon-we-in - the.

The exercise model above is also not constructively valid and is not appropriate for listening tests. This exercise can be answered correctly by students without listening to the sound in audio. This type of exercise is usually used for grammar tests. This exercise model should not be used in listening tests.

\section{The third example}

In audio, students hear:

Number one : There are seven days in a week.

Number two : The day before Monday was Tuesday.

In textbook, it is written:

Direction: Listen the audio carefully and complete the sentences below!

1. There are days in a week.

2. The day after was Tuesday.

The exercise model above is usually used for vocabulary test. If students have good vocabulary or reading skills, students can answer the questions without listening to sounds in the audio. The right exercise model for the material above is the multiple-choice as follows:

1. Audio: There are / pause / days in a week.
Textbook: A. 4
B. 5
C. 6
D. 7

2. Audio: The day after Monday was / pause /.
Textbook: A. Monday
B. Tuesday
C. Wednesday
D. Thursday

The improvement efforts were made to solve teachers' problem and to revise teachers' material design:

1. Teachers were taught to find the right keywords by changing keywords in searching for the right video.

2. Teachers firstly determined and wrote listening exercise in form of worksheet then edit video based on the exercise.

3. Teachers were guided to reformulate invalid materials. 
The teacher revised the material by practicing cutting videos, merging videos, giving space between one number and others, and entering music in the beginning and the end of each activity.

\subsubsection{Implementation and Evaluation}

Teachers' products (English listening audio and textbook) were used in teaching listening in teachers' classrooms. Teachers and researchers tried to evaluate the product feasibility. It was conducted to evaluate the level of use of the design. It was measured by the convenience of the user in using it, in this case the teacher and students. Evaluation of product feasibility by teacher was related to the use the product in terms of: (1) playing audio material on laptop and (2) providing task instructions for the students. While the evaluation of product feasibility by students was related to: (1) sound clarity, (2) speed level, (3) clarity of instructions, (4) difficulty level, and (5) exercise model.

In implementation, teachers didn't get difficulties in playing audio material, however they still need to provide task instruction for the students because the direction was not available in audio. While, students found unclear sound quality, the speed was too fast so students got difficulty in listening and answering listening exercise and the teacher must replay the video many times.

Interview data showed that the product still has some weakness:

1. No direction in the audio, so students still need verbal instructions from the teacher.

"There is no direction in each activity so students still need direction in the beginning and the end of each activity."

2. The level of difficulty in the completion exercise model is considered high.

"Most of the children are success in answering multiple-choice, but most of them fail in completion".

The data showed that the product needed revision to improve the quality and validity of teachers' product.

\subsubsection{Revision}

After analyzing the implementation of the product, the efforts made to improve the product were:

1. Changing videos that have unclear sound quality.

2. Cutting videos and merging videos by giving enough pauses between one number and another number.

3. Putting music at each turn of activity or exercise and at the end of the activity.

4. Putting direction at the beginning of the chapter as general direction.

5. Changing listening practice model that was considered too difficult. Some completion exercises were changed into true-false and multiple-choices model.

\subsubsection{Implementation and Evaluation}

After revising the product, it was used in teaching listening skill. In the implementation, teachers didn't get difficulties in playing audio material, but they still need to provide task instruction for each activity because the general direction in beginning of each chapter cannot be used as task direction for each activity because they contain different exercise 
model, so students still need verbal instructions from teacher. However, it was not considered a significant difficulty by teachers. The following interview data showed teachers' perceptions toward product:

"It's comfortable to use."

"It's really very easy for teachers to deliver teaching material."

The data above showed that this product was feasible to use. Students also didn't complain about sound quality and speed level anymore.

\subsubsection{Final Product}

Teachers' English listening material designs (products) in this training were textbook and audio material in $C D$ and flash disk. The products can be accessed in https://drive.google.com/drive/folders/1WeoNtgJLUzdPN3EWdlpDSzuUSsOPulUp?usp=sha ring.

Teachers' English listening materials design consists of five chapters. Chapter 1 is greeting, chapter 2 is self-introduction, chapter 3 is asking information 1 (time and place), chapter 4 is asking information 2 (things in the classroom), and chapter 5 is giving direction and instruction. Each chapter contains 9 to 12 activities. Each activity contains phoneme discrimination and listening comprehension exercise in 3 models, multiple choices, completion, and true-false.

Each chapter consists of general direction and specific direction. General direction lays on the beginning of each chapter and specific direction lays on each activity in a chapter. General direction is available in audio and textbook. The general direction as below:

This listening section measures your ability to understand conversation and lecture in English. You'll hear each conversation and lecture in only one time. After each conversation and lecture, you'll hear some questions about it. Answer the questions based on what the speaker states in playing.

However, specific direction is only available in textbook. The examples of specific direction are listen carefully then circle $T$ for the correct statement or circle F for the false statement or listen carefully and complete the following dialogue. Teachers cannot find video that contains specific direction. To solve problem in giving direction for each activity, teachers decide to put the direction in textbook so students can read the direction. Teachers also give direction orally.

Phoneme discrimination exercise aims to improve students' ability in identifying sound. In this exercise, students hear from audio "I am very well, thank you". In worksheet, it is written: A. I am very wet now, B. I am very well, thank you, and C. I am very bed, thank you. Students have to find the sentence (correct answer) they hear from audio by choosing one of three sentences in worksheet $(A, B$, or $C)$. Two other sentences are distracters. It is made as similar to correct answer as possible.

Listening comprehension exercise aims to improve students' ability understanding word, monologue and dialogue. For example, students hear word from the audio "number one: "book", then students have to find the book's picture by choosing one of four pictures ( $A, B$, C, or D) which are available in textbook. 


\subsection{Teachers' ability in designing English listening materials}

Teachers' ability was divided into: (1) ability in editing video that include importing, exporting, cutting, deleting, and merging videos, and (2) ability in designing listening exercises.

After getting training and mentoring in designing audio English listening teaching materials, the data analysis about teachers' ability was administered below:

\subsubsection{Ability in editing video}

Teachers' ability to edit video for English listening practice was categorized into proficient and capable.

A teacher was categorized into good when:

1. The teacher does not need assistance to use computer, download videos, and edit videos.

2. The teacher does not use very long time in editing videos

A teacher was categorized fair when:

1. The teacher still needs assistance in editing videos.

2. The teacher uses a very long time to edit videos.

Table 1: Teachers' ability in editing video

\begin{tabular}{llcccc}
\hline \multirow{2}{*}{ No } & \multirow{2}{*}{ Activity } & \multicolumn{4}{c}{ Ability } \\
\cline { 3 - 6 } & & Frequency & Percentage & Frequency & Percentage \\
\cline { 2 - 6 } & 12 & $67 \%$ & 6 & $33 \%$ \\
\hline 1 & Download video & 11 & $61 \%$ & 7 & $39 \%$ \\
2 & Import and export video & 10 & $56 \%$ & 8 & $44 \%$ \\
3 & Cut video & 9 & $50 \%$ & 9 & $50 \%$ \\
4 & Merge video & & & & Fair \\
\hline
\end{tabular}

Data showed that after following training, teachers have good ability at editing video for English learning materials. $67 \%$ of teachers have a good ability to download quality videos and are suitable for listening learning goals. $61 \%$ teachers are good at importing and exporting video, 56\% teachers are good at cutting video, and 50\% teachers are good at merging video.

Data showed that the difficult activities of editing video are cutting and merging video. It was supported by interview data below:

"... cutting a video takes a long time for me because I'm not used to do it so I need a long time."

"When we want to cut a sentence, we are constrained by the speed of sound of the video."

"During the process of cutting the video, when we want to take it, sometimes we find it difficult to fit."

"The obstacle I faced when making the product was connecting one video with another video."

"The obstacles are still confused about how to cut, merge videos." 
The results of the interview above showed that the most difficult editing process is the process of cutting the video. The difficulties are: (1) the sound (conversation or statement) in the video is too fast, and (2) the sound to be taken is too short (usually only in the form of words, phrases or short sentences), so the teacher has difficulty in determining the boundary of the scene or conversation will be cut. The difficulty in determining the sound or scene caused the teacher took a long time to edit the video. Furthermore, errors in the cutting process cause errors in video merging.

\subsubsection{Ability in writing listening exercises}

Teachers' ability in writing English listening exercise is divided into good and fair.

The indicators of good are as follows:

1. The teacher is able to make tests with normal difficulty levels.

2. The teacher is able to make valid tests (content validity and construct validity).

3. The teacher is able to reformulate the utterances of monologue or dialogue in video into exercise in the worksheet.

The indicators of fair are as follows:

1. The teacher is able to make a test but the level of difficulty is still too high.

2. The teacher is able to make valid tests in content but not in construct (see example 1, 2, and 3 in training).

3. The teacher is not able to reformulate the utterances of monologue or dialogue in video into exercise in the worksheet (see example 1 in training).

The following chart illustrates teachers' ability in designing English listening test.

Table 2: Teachers' ability in writing listening exercise

\begin{tabular}{clcc}
\hline No & Teacher's Ability & Frequency & Percentage \\
\hline 1 & Good & 13 & $72 \%$ \\
2 & Fair & 5 & $28 \%$ \\
\hline
\end{tabular}

The table showed that most of teachers have a good ability in writing English listening exercise. $75 \%$ teachers are categorized into good but only $28 \%$ teachers are categorized into fair.

\subsection{The effect of teachers' product toward English listening learning}

To find out the effect of teachers' product toward English listening learning, analysis was conducted toward students' learning outcomes and students' attitude in learning listening by using the product.

\subsubsection{Students' learning outcomes}

Student learning outcomes are presented in the form of mean scores, frequency, and percentage, and learning outcomes categories. 
Students' learning outcomes is shown in the following table:

Table 3. Students' score

\begin{tabular}{clcc}
\hline No & \multicolumn{1}{c}{ Exercise model } & Mean score & Category \\
\hline 1 & Phonem discrimination & 64 & Fair \\
2 & Listening comprehension & 63 & Fair \\
\hline
\end{tabular}

The table showed that the students' listening is categorized into fair. Students are fair to identify sound in form word and sentences and to understand messages in conversations, explanations, and instructions well.

Table 4. Category of students' learning outcome

\begin{tabular}{llcccc}
\hline \multirow{2}{*}{ No } & \multirow{2}{*}{ Category } & \multicolumn{4}{c}{ Exercise model } \\
\cline { 3 - 6 } & & \multicolumn{2}{c}{ Phonem discrimination } & \multicolumn{2}{c}{ Listening comprehension } \\
\cline { 3 - 6 } & & Frequency & Percentage & Frequency & Percentage \\
\hline 1 & Very good & 40 & $27 \%$ & 15 & $10 \%$ \\
2 & Good & 50 & $33 \%$ & 65 & $43 \%$ \\
3 & Fair & 5 & $3 \%$ & 10 & $7 \%$ \\
4 & Poor & 55 & $37 \%$ & 60 & $40 \%$ \\
\hline
\end{tabular}

The table showed that more than $60 \%$ students were able to identify and understand verbal messages. From 150 students, 40 students were categorized into very good, 50 students were good, and 5 students were fair. However, 55students were still categorized into poor.

Students' score showed that the teaching material products made by the teacher have positive effect toward student learning outcomes. Students' listening skills were categorized into fair and the number of students categorized into very good and good is bigger than the number of students categorized into poor.

Effective learning is constructing students' knowledge and skill by monitoring and review learning process to achieve particular goals (C. Watkins, Lodge, Whalley, Wagner, \& Carnell, 2002). The objective of listening learning is students are able to understand short and simple oral functional text by identifying specific information in verbal messages and complete written text based on verbal messages (Kebudayaan, 2012). It implies that the teachers' product is effective to achieve the objective of listening learning. Even though students' mean score is in fair level, more than 60\% students are success in answering phoneme discrimination and listening comprehension exercise.

Therefore further research is called to measure the effectiveness of this product by using other research method. It is expected to measure the significant improvement of students' listening skills. This study also measured students' learning outcome through exercise on the product. Therefore, other listening test should be used to measure students' listening skills to ensure the effectiveness of this product.

\subsubsection{Students' learning attitude}

Teachers' product not only affects student learning outcomes but also student learning attitudes. Based on interview data from teachers shows that students have positive attitude in learning listening by using the products. Students are serious in learning listening by 
using the product. Students don't make noisy and talk to their friends during listening learning process. They also focus on the listening materials.

"Teaching using this learning media, students are not noisy in class. They concentrate on listening to learning material. Previously, when teachers taught sometimes they still talked to their friends".

"After I use this material in class, students become calm. Previously I was rather difficult to deal with students because they were noisy and they talked to their friends. However, by using this material, students were more focused on listening to the material in the audio."

Using the product makes students fun in learning listening skills.

"The positive thing is that students make it as a refreshing material."

This product is able to be a medium for refreshment or ice breaker. It can be used to attract students' attention by teaching listening materials in beginning or ending of class. Seçer, Şahin, \& Alcı (2015) stated that audio visual material is a proper ice breaker that gives positive effect toward students' motivation and participation in learning English. The findings indicate that students' attitudes in learning listening by using teachers' product are learning seriously and learning fun.

\section{Discussion}

YouTube editing video training is considered effective to improve teachers' ability in designing English listening materials. Most teachers are categorized into good in designing listening materials by editing YouTube video. Teachers can design the materials independently where data showed that most teachers don't need long time and assistance from trainee to download, import, cut, merge, and export video. Previously, teachers avoid teaching listening skills because they get difficulty to find out the materials and they get confusing to teach the skill. However, after following the training, teachers have had their own English listening materials and they can improve their materials if they need improvement because teachers' have knowledge and skill in designing English listening materials. Omar (2014) stated that teachers' training aims to prepare learning situation for teachers to develop their professional work that can help teachers to face challenge and change in teaching. It indicates that YouTube editing training is effective to develop teachers' knowledge and skill because teachers are able to prepare their English listening materials by themselves in form of audio material and textbook to solve their problem in teaching listening skills.

Teachers' material designs (audio and textbook) are feasible to use in teaching English listening skill. The material contents are in accordance with English curriculum objective, authentic, and easy to use. This material designs were in line with guidelines offered by Howard \& Major (2004). They are (1) teaching materials should be contextualized to curriculum, (2) be authentic, and (3) encourage learners to develop learning skill and strategies. Moreover, Ahmed (2017) stated that good teaching materials contain language input for developing students' skills, appropriate difficulty level, authentic, and interesting. Then, Watkins \& Wilkins (2011) stated that YouTube prepared variety of English dialects. It is also easy to access and enjoyable for students. It implies that the listening material 
designs have fulfilled good teaching materials requirements because they contain materials from YouTube video which prepare many authentic and interesting materials for listening skills.

Teachers' material designs in form of audio and textbook are also effective in teaching English listening skill. Most students can identify English sound in form of word and sentence and they also can understand simple and short monologue and dialogue. Students also showed positive attitude in learning English listening skill when teachers used these materials in teaching them. This finding is supported by Sabet \& Mahsefat (2012). They reported that authentic listening materials have positive effect to students' listening skills. Alqahtani (2014) also reported that YouTube is effective in teaching listening skills. Then, Saputra \& Fatimah (2018) stated that YouTube is effective instructional media for teaching listening skills. It can be said that this training is success to update and to develop teachers' knowledge and skills to solve teachers' and students' problems in listening skills. Teachers can prepare their English listening materials by using the potency they have. Teachers' products are also effective to achieve the learning objective of listening skills and to form students' positive attitude toward listening skills learning.

\section{Conclusion}

Listening skills are skills that are almost never taught by the teachers. They ignored to teach English listening skills because of some reasons. First, listening cassette or CD is hard to find; second, English textbooks don't prepare teaching materials for listening skill/textbooks are not equipped with listening audio material or $C D$; third, price of listening materials is expensive; fourth, the materials difficulty level isn't suitable for junior high school students; and fifth, teachers aren't able to prepare English listening material by themselves. These reasons are in line to the findings of Le (2019) that teachers' difficulties in teaching listening skills are the lack of listening facilities and teachers' ability in mastering listening skills and preparing teaching method for listening skills. Therefore, YouTube video editing training was conducted to help teachers in providing English listening materials by considering some potency in Parepare city. They are: (1) teachers have computer, laptop, and smartphone, (2) internet network is very good, and (3) internet credit is cheap.

YouTube video editing training was administered in two activities, training and mentoring. Training aimed to design English listening materials in form of audio and worksheet; and mentoring aimed to revise teachers' products. Teachers have good ability in designing English listening material after following the training. Teachers' products are already suitable for use in teaching English listening skill. They have positive effect toward students' English listening learning outcome and students' attitude in learning English listening skill.

\section{References}

Ahmed, S. (2017). Authentic ELT Materials In The Language Classroom: An Overview. Journal Of Applied Linguistics And Language Research, 4(2), 181-202.

Almurashi, W. A. (2016). The Effective Use Of Youtube Videos For Teaching English Language In Classrooms As Supplementary Material At Taibah University In Alula. International Journal Of English Language And Linguistics Research, 4(3), 32-47.

Alqahtani, E. T. (2014). Effectiveness Of Using Youtube On Enhancing EFL Students' Listening Comprehension Skills. Saudi Arabia. 
Alrawashdeh, A. I., \& Al-Zayed, N. N. (2017). Difficulties That English Teachers Encounter While Teaching Listening Comprehension And Their Attitudes Towards Them. English Language Teaching, 10(5), 167-178.

Bingol, M. A., Celik, B., Yildiz, N., \& Mart, C. T. (2014). Listening Comprehension Difficulties Encountered By Students In Second Language Learning Class. Journal Of Educational \& Instructional Studies In The World, 4(4).

Chen, C. W. (2016). Listening Diary In The Digital Age: Students' Material Selection, Listening Problems, And Perceived Usefulness. Jalt Call Journal, 12(2), 83-101.

Gilakjani, A. P., \& Sabouri, N. B. (2016). Learners' Listening Comprehension Difficulties In English Language Learning: A Literature Review. English Language Teaching, 9(6), 123133.

Hamouda, A. (2013). An Investigation Of Listening Comprehension Problems Encountered By Saudi Students In The EL Listening Classroom. International Journal Of Academic Research In Progressive Education And Development, 2(2), 113-155.

Hayati, A. (2010). The Effect Of Speech Rate On Listening Comprehension Of EFL Learners. Creative Education, 1(02), 107.

Howard, J., \& Major, J. (2004). Guidelines For Designing Effective English Language Teaching Materials. The TESOLANZ Journal, 12(10), 50-58.

Johansson, T. (2006). Teaching Material In The EFL Classroom: Teachers' And Students' Perspectives.

Kadagidze, L. (2006). Different Types Of Listening Materials. IBSU Scientific Journal, 1(1), 148-154.

Kebudayaan, K. P. D. (2012). Kurikulum 2013 SMP. Jakarta: Kementerian Pendidikan Dan Kebudayaan.

Kebudayaan, K. P. D. (2015). Pedoman Teknis Penilaian Hasil Belajar. Jakarta: Kementerian Pendidikan Dan Kebudayaan.

Le, T. M. (2019). Teaching Listening Skills For English Non-Majored Students At Ba Ria-Vung Tau University: Difficulties And Solutions.

Mafuraga, M., \& Moremi, M. (2017). Integrating Information And Communication Technology In English Language Teaching: A Case Study Of Selected Junior Secondary Schools In Botswana. International Journal Of Education And Development Using ICT, 13(1).

Omar, C. M. Z. (2014). The Need For In-Service Training For Teachers And It's Effectiveness In School. International Journal For Innovation Education And Research, 2(11), 1-9.

Osada, N. (2004). Listening Comprehension Research: A Brief Review Of The Past Thirty Years. Dialogue, 3(1), 53-66.

Plomp, T. (2013). Educational Design Research: An Introduction. Educational Design Research, 11-50.

Renandya, W. A., \& Farrell, T. S. C. (2011). 'Teacher, The Tape Is Too Fast!'Extensive Listening In ELT. ELT Journal, 65(1), 52-59.

Renukadevi, D. (2014). The Role Of Listening In Language Acquisition; The Challenges \& Strategies In Teaching Listening. International Journal Of Education And Information Studies, 4(1), 59-63.

Ross, J. (2007). Designing Lessons For EFL Listening Comprehension Classes. English Teaching Forum, 45(3), 30-33. ERIC.

Sabet, M. K., \& Mahsefat, H. (2012). The Impact Of Authentic Listening Materials On 
Elementary EFL Learners' Listening Skills. International Journal Of Applied Linguistics And English Literature, 1(4), 216-229.

Saputra, Y., \& Fatimah, A. S. (2018). The Use Of TED And YOUTUBE In Extensive Listening Course: Exploring Possibilities Of Autonomy Learning. Indonesian JELT, 13(1), 73-84.

Seçer, Ş. Y. E., Şahin, M., \& Alcl, B. (2015). Investigating The Effect Of Audio Visual Materials As Warm-Up Activity In Aviation English Courses On Students' Motivation And Participation At High School Level. Procedia-Social And Behavioral Sciences, 199, 120-128.

Sejdiu, S. (2017). Are Listening Skills Best Enhanced Through The Use Of Multimedia Technology. Digital Education Review, (32), 60-72.

Tomlinson, B. (2012). Materials Development For Language Learning And Teaching. Language Teaching, 45(2), 143-179.

Watkins, C., Lodge, C., Whalley, C., Wagner, P., \& Carnell, E. (2002). Effective Learning. Institute Of Education, University Of London.

Watkins, J., \& Wilkins, M. (2011). Using Youtube In The EFL Classroom. Language Education In Asia, 2(1), 113-119.

Woottipong, K. (2014). Effect Of Using Video Materials In The Teaching Of Listening Skills For University Students. International Journal Of Linguistics, 6(4), 200.

Yavuz, F., Değirmenci, N., Akyüz, S., Yılmaz, H., \& Çelik, Ö. (2015). Problems And Activities In Listening Skills In EFL Classrooms; From Tradition To A More Comprehensible Input. 